\title{
BERENDEZÉS TERVEZÉSE KIS ÉS KÖZEPES MÉRETÜ CSOMAGOLÁSOK EJTŐ VIZSGÁLATÁHOZ
}

\author{
Majoros Péter \\ hallgató, Miskolci Egyetem, Gép- és Terméktervezési Intézet \\ 3515 Miskolc, Miskolc-Egyetemváros, e-mail: majorospeter@gmail.com \\ Takács Ágnes \\ egyetemi docens, Miskolci Egyetem, Gép-és Terméktervezési Intézet \\ 3515 Miskolc, Miskolc-Egyetemváros, e-mail: takacs.agnes@uni-miskolc.hu
}

\begin{abstract}
Absztrakt
Napjainkban világszerte egyre jellemzöbb az online vásárlás, melynek köszönhetöen a csomagszállitás egyre nagyobb méreteket ölt. Elengedhetetlen az áruk védelme és a vevök elégedettsége érdekében a megfelelö csomagolás biztositása. A cikk egy olyan feladatot ismertet röviden, melynek témája egy csomagolás tesztelö berendezés tervezése.
\end{abstract}

Kulcsszavak: tervezés, csomagolás, tesztelö berendezés

\section{Abstract}

Nowadays, online shopping is becoming more and more popular all over the world. It is important to ensure proper packaging for the protection of the goods and customer satisfaction. The paper shortly introduces a design task that is about a package testing equipment.

Keywords: design, package, testing device

\section{Bevezetés}

A csomagokat érő terhelések lehető legmagasabb szintü reprodukálása végett, a cél egy ejtővizsgáló berendezés tervezése (1. ábra), amely alkalmas kis- és közepes méretü csomagok (maximum $600 \mathrm{~mm} x$ $360 \mathrm{~mm}$ x $620 \mathrm{~mm}, 25 \mathrm{~kg}$ ) vizsgálatára egyaránt [5]. A vizsgálat menete: különböző, jól meghatározott pozíciókban (lapjára, élére, sarkára) elhelyezve a csomagot, a vizsgálati magasság beállítását követően egy merev talpazatra ejtik a csomagot.

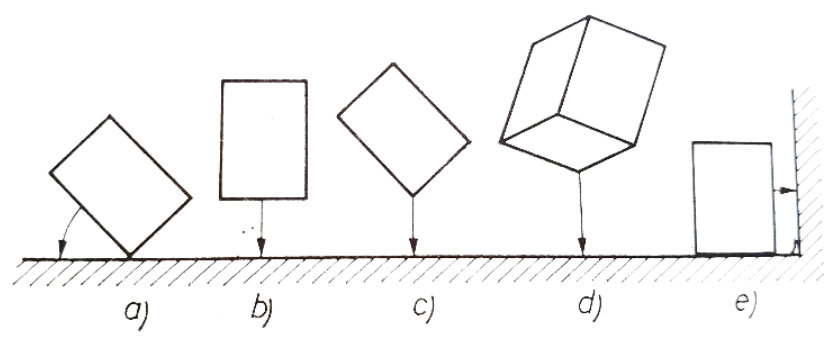

1. ábra. Ejtési igénybevételek 
A tervezés során figyelembe kell venni, hogy a cél egy prototípus berendezés megépítése, nem pedig sorozatgyártás továbbá, hogy a Gép- és Terméktervezési Intézetben számos ISEL elem rendelkezésre áll, így a konstrukciós megoldás során törekedtem az ISEL cég katalógusából (www.isel.hu) kiválasztani a szükséges elemeket.

Ötletgyüjtés céljából a www.espacenet.com és a www.google.hu/PATENTS oldalak segítségével szabadalomkutatás elvégzésére került sor. Emellett piackutatás is történt. Ezek eredményeképpen többek között olyan hasznos funkcionális részegységek kerültek megfogalmazásra, mint a billenő tálca, amelyről a vizsgált csomagot le lehet ejteni, vagy a pozicionáló rúd, amivel pozícióban lehet tartani a csúcsára állított csomagot. A feltárt funkcionális részegységekből különféle koncepcionális megoldásváltozatok készültek, melyeket Copeland módszerrel értékelve kiválasztásra került az az elvi megoldásváltozat, amely a további tervezési munkálatok alapját képezi $[6,7]$.

A konstrukciós tervezés kezdeti szakaszában a tálca pozíciójának beállítására három különféle megoldási elv került elemzésre:

- fogaskerék-fogasléc kapcsolat,

- targonca jellegü felvonó,

- emelőorsós megoldás.

Konstrukciós okokból a továbbiakban ez utóbbi, emelőorsós változat került kidolgozásra.

\section{Az emelőorsós változat kidolgozása}

A konstrukciós tervezés első lépéseként a 2. ábra szerinti kinematikai ábra készült el. A berendezés egy vízszintes, merev bázisfelülettel rendelkezik (1), amelyre a függőleges vázszerkezet (2) épül. A kettő között kerül rögzítésre az emelő orsó (3), valamint egy támasztó tengely (4). A támasztótengely az orsó hajlító terhelését fogja csökkenteni, így egy kisebb orsó is képes betölteni az emelő funkciót. Az orsóhoz kapcsolódik maga a tálca (5) és az orsót egy tengelykapcsolón (6) keresztül forgatjuk meg egy villanymotor (7) segítségével.

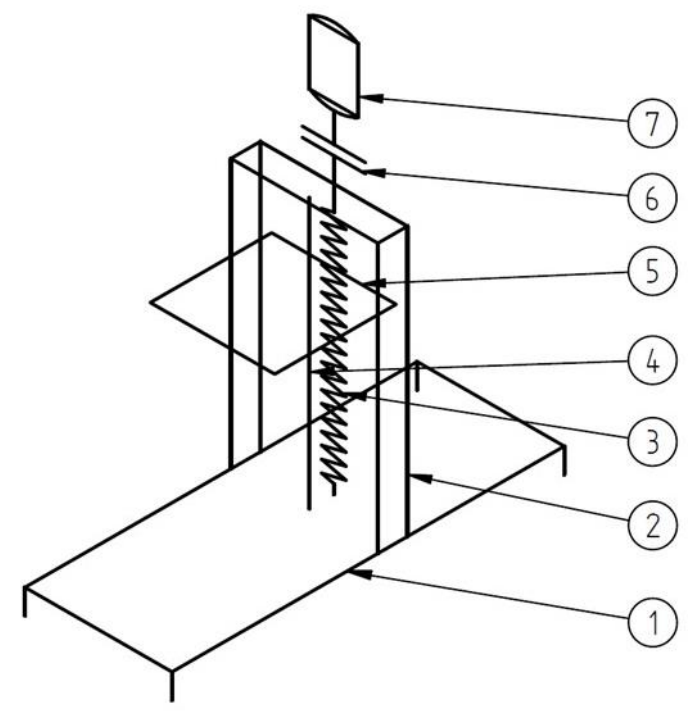

2. ábra. A berendezés kinematikai vázlata 
A konstrukciós tervezés során az alábbi területek kerültek vizsgálat alá:

- tálca profil megválasztása,

- lineáris vezetékek kiválasztása,

- a támasztó tengely méretezése,

- orsó méretezése,

- motorválasztás,

- csapágyválasztás,

- tengelykapcsoló választás,

- reteszkötés méretezése.

\section{A végleges megoldás}

A konstrukciós tervezés után, szabadkézi vázlatok és az előzetes vázlatos modell alapján elkészült a berendezés 3. ábra szerinti 3D-s modellje Solid Edge (ST9) környezetben. (1)-el jelölve látható a motor, (2)-vel az acéllemezek. A (3)-mal jelölt elemek képezik a függőleges vázszerkezetet, valamint hátul egy $45^{\circ}$-os szögben döntött merevítőt. A felső csapágyazás a (4) jelü, a lineáris vezetékek az (5) jelet kapták, a görgős kocsik a (6) jelet. A (7) támasztótengely, amely egy csuszkán keresztül kapcsolódik a (8) tálcatartóhoz. Ehhez van rögzítve a (9) kioldószerkezet, melyet hátulról, a tálca alól kihúzva végezhető el a tálca billentése. Szintén a (8) tálcatartóhoz kapcsolódik még két oldalt egy-egy csuklón keresztül a (10) billenő rész. Az alsó csapágyazás a (11) jelet kapta, az alsó vázszerkezet pedig a (12) jelet. A (13) jelü állítható talpak a szintezést teszik lehetővé.

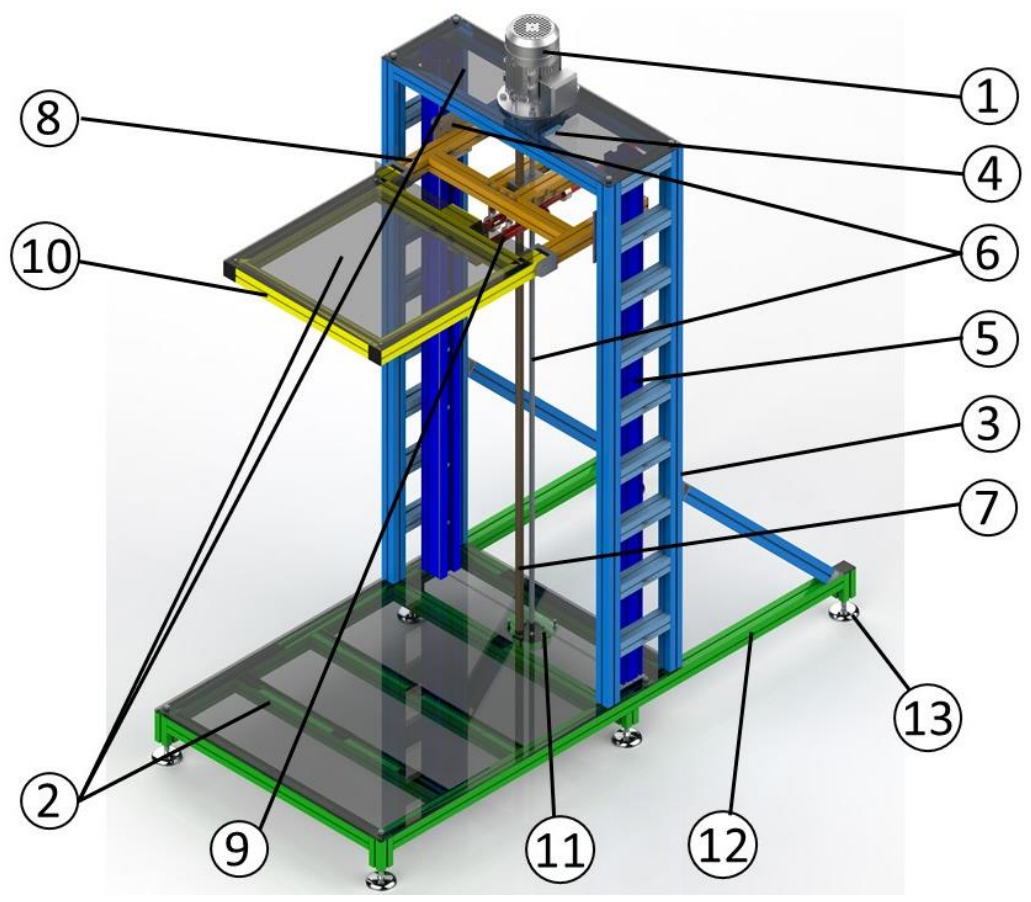

3. ábra. A végleges megoldás $3 D$ modellje 


\section{4. Összefoglalás}

A tervezési folyamat első részében az ötletek gyüjtésén és szelektálásán volt a hangsúly, ami a korábbi szabadalmak és a már meglévő, hasonló célra kifejlesztett berendezések elemzésével történt. A szükségesnek vélt funkcionális részegységek alapján megoldásváltozatok megfogalmazására került sor. A megoldásváltozatok értékelemzése alapján a legjobbnak bizonyuló kialakítás képezte a további tervezési feladatok alapját. Solid Edge ST9 szoftver segítségével a berendezésról egy 3D-s modell készült. A modell alapján elkészült az a kinematikai vázlat, amely a konstrukciós számítások alapjául szolgált.

A konstrukciós tervezés során megtörtént az orsó és a lineáris vezetékek kiválasztása az ISEL cég katalógusából, majd azoknak a mérnöki számítások alapján történő ellenőrzése. A berendezés müködéséhez megfelelő motort is kellett választani. Ezek után a vázszerkezet optimális profilját és az egyéb szükséges gépépítő elemeket is meg kellett határozni [1], [2], [3], [4]. A távlati tervek közt szerepel a berendezés megépítése.

\section{Köszönetnyilvánítás}

A cikkben ismertetett kutató munka az EFOP-3.6.1-16-2016-00011 jelü „Fiatalodó és Megújuló Egyetem - Innovatív Tudásváros - a Miskolci Egyetem intelligens szakosodást szolgáló intézményi fejlesztése" projekt részeként - a Széchenyi 2020 keretében - az Európai Unió támogatásával, az Európai Szociális Alap társfinanszírozásával valósul meg.

\section{Irodalom}

[1] Zsáry, Á.: Gépelemek I., Nemzeti Tankönyvkiadó, Budapest, 1989, ISBN 9631945855

[2] Zsáry, Á.: Gépelemek II., Nemzeti Tankönyvkiadó, Budapest, 1991, ISBN 96318 6443X

[3] Herczeg, I.: Szerkesztési atlasz, Müszaki Könyvkiadó, Budapest, 1976, ISBN 9631007901

[4] Péter, J.: A géptervezés alapjai, Miskolci Egyetemi Kiadó, Miskolc, 2017, ISBN 978963661 8377

[5] Rockstroh, O.: Csomagolástechnika kézikönyv, Müszaki Könyvkiadó, Budapest, 1979, ISBN 9631032795

[6] Takács, Á.: Computer Aided Concept Building, Solid State Phenomena 261, 2017, pp. 402407., ISSN 1662-9779, https://doi.org/10.4028/www.scientific.net/SSP.261.402

[7] Takács, Á.; Kamondi, L.: On Design Theories: Fundamentals of a Neuvel Approach, Advanced Engineering Vol 5, No 1, 2011, pp. 109-118., ISSN 1846-5900 